Eur. J. Clin. Chem. Clin. Biochem.

Vol. 32, 1994, pp. 137-143

C 1994 Walter de Gruyter \& Co.

Berlin - New York

\title{
Thyroglobulin is a More Sensitive Indicator of Iodine Deficiency than Thyrotropin: Development and Evaluation of Dry Blood Spot Assays for Thyrotropin and Thyroglobulin in Iodine-Deficient Geographical Areas
}

\author{
By U. Mißler ${ }^{1}$, R. Gutekunst ${ }^{2}$ and W. G. Wood $^{3}$
}

' Klinik für Neurochirurgie, Medizinische Universität zu Lübeck, Lübeck, Germany

2 ICCIDD Study Group, Division of Endocrinology, University of Virginia Medical Center, Charlottesville, USA

${ }^{3}$ Institut für Klinische Laboratoriumsdiagnostik, Klinikum der Hansestadt Stralsund, Stralsund, Germany

(Received September 30, 1993/January 4, 1994)

Summary: Immunometric assays were developed for thyrotropin and thyroglobulin using time-resolved fluorescence as the measurement signal. The assays were suitable for measurements in serum/plasma or in dry blood spots ( $3 \mathrm{~mm}$ diameter).

Both assays have acceptable coefficients of variation for dry blood spots (intra-assay median CV $<10 \%$, interassay $\mathrm{CV}<15 \%$ ) in the concentration range of interest (thyrotropin 3-250 mU/l, thyroglobulin $10-500 \mu \mathrm{g} / \mathrm{l})$. The relatively high $\mathrm{CV}$ values are not only due to the assay design but also to the inhomogeneity of the samples used. For serum samples the median intra-assay $\mathrm{CV}$ was $<3 \%$ for thyrotropin in the range $0.1-50 \mathrm{mU} / \mathrm{l}$ and for thyroglobulin between 2 and $500 \mu \mathrm{g} / \mathrm{l}$. The corresponding inter-assay $\mathrm{CV}$ were less than $5 \%$.

The assays were evaluated in field studies carried out under auspices of International Council for Control of Iodine Deficiency Disorders (ICCIDD) with the support of UNICEF in Algeria, Peru, India and Zimbabwe, and were found to be practical inasmuch as dry blood spot samples could be transported without special precautions for up to 5-6 weeks without significant loss in immunoreactivity. This agrees with other findings.

The results showed that serum thyroglobulin levels are a more sensitive indicator of iodine deficiency than thyrotropin; elevated thyroglobulin levels were found in 182/304 children in Zimbabwe compared with elevated thyrotropin level in 28/304 cases. 213/304 children had enlarged thyroid glands. The cut-off levels used here were $4.5 \mathrm{mU} / \mathrm{l}$ thyrotropin and $20 \mu \mathrm{g} / 1$ for thyroglobulin, both in whole blood.

The assays proved useful for assessing the efficacy of iodine therapy, either by oral dosage or intramuscularly (iodised oil). Single oral doses between 120 and $960 \mathrm{mg}$ iodine were used, and the single intramuscular dose contained $480 \mathrm{mg}$ iodine. Both serum and dry blood spots were analysed. Single oral doses of 480 and $960 \mathrm{mg}$ iodine resulted in normalisation of serum thyroglobulin levels. The same was true for the $480 \mathrm{mg}$ iodine given intramuscularly. Lower single doses did not reduce elevated thyroglobulin levels to normal values.

The assay could also be used to determine/confirm athyroidism in newborns, results being available within 6 hours.

\section{Introduction}

Dry blood spot tests for congenital hypothyroidism in newborns, using thyrotropin and/or thyroxine as analyte, has/have become a routine diagnostic tool $(1-3)$. Serum thyrotropin concentration has also been used to assess iodine deficiency in recent years (4).
Screening for iodine deficiency in remote areas is problematic, because the processing of blood and urine samples on-site is often impractical or impossible $(5,6)$. The determination of thyrotropin or thyroglobulin and urinary iodide is only possible in specialised laboratories. These problems have led to the search for solu- 
tions which are practical and which are independent of the geographical location.

This article describes the development and evaluation of dry blood spot assays based on a time resolved fluorescence immunoassay technique, coupled with an infield evaluation using both serum and blood spot samples. Samples were obtained during studies carried out by the International Council for Control of Iodine Deficiency Disorders (ICCIDD) in conjunction with UNICEF.

Preliminary results from this group suggest that the most sensitive single quantity for the determination of iodine deficiency is probably thyroglobulin, and not thyrotropin or urinary iodide. We therefore developed an assay for thyroglobulin in dry blood spots and compared it with the determination of thyroglobulin in serum.

The methods used were modifications of methods already published $(7,8)$, specially developed for blood spots of $3 \mathrm{~mm}$ diameter, using a one-step immunometric assay procedure with biotinylated antibodies and streptavidin-europium as marker substance. Both assays had identical incubation times and could be performed within a single working day.

The dry blood spots could be carried in a brief case at ambient temperature, with no decrease of immunoreactivity over a 28 day period at temperatures between -5 and $+45^{\circ} \mathrm{C}$ and relative humidities between $<10$ and $>90 \%$. The only precaution was the storage of filter papers in individual cellophane envelopes within 120 minutes after blood sampling.

The studies were carried out on school children in geographical areas of known iodine deficiency. For controls, we used children in the Federal Republic of Germany with normal values for thyroid size and thyroid related analytes (thyrotropin, free thyroxine, free triiodothyronine, antibodies to thyroid peroxidase and thyroglobulin).

\section{Materials and Methods}

\section{Materials}

Antibodies to thyroglobulin were purchased from DAKO, Hamburg, Germany, those against thyrotropin from Boehringer Mannheim, Mannheim, Germany.

Filter paper for blood spots and whole blood standards was obtained from Schleicher \& Schüll, Dassel, Germany.

Microtitre plates (96-well - Maxisorp) were bought from Nunc, Roskilde, DK.

Standards for thyrotropin (Kabi-Pharmacia, Erlangen, Germany) were made up in EDTA-blood and were calibrated against blood spot standards for thyrotropin (Pharmacia, Uppsala, Sweden). Standards for thyroglobulin were made up using standard material supplied by Henning-Berlin, Berlin, Germany.
Blocking antibodies (MAK-33) and streptavidin were purchased from Boehringer-Mannheim.

Buffer substances and detergents were obtained from Merck, Darmstadt, Germany and Sigma, Deisenhofen, Germany, Europium-labelling reagent from Pharmacia.

Test kits used for comparison were purchased from Pharmacia (DELFIA), Henning-Berlin (Lumitest) or Behringwerke, Marburg a.d.L., Germany (Berilux).

\section{Methods}

Assays for thyrotropin and thyroglobulin

Two-site immunofluorimetric assays using europium as signal were developed for thyroglobulin and thyrotropin using microtitre plate technology. The assays could be applied to either serum or dry blood spots.

The liquid phase antibodies were biotinylated, the marker substance being streptavidin-europium. The assay principle was that of dissociated enhanced lanthanide fluorescence (DELFIA). Details of the thyrotropin assay have already been published in this journal (7). The thyroglobulin assay was identical to the thyrotropin assay, with the exception of the antibodies, which were the same as those used for routine analysis (10).

Serum thyrotropin tests were carried out using the Berilux TSH immunoluminometric assay (Behringwerke). Serum thyroglobulin tests were performed with an in-house immunoluminometric test as published elsewhere (10), or with the Lumitest $\mathrm{Tg}$ assay from Henning-Berlin.

Tables la and $1 \mathrm{~b}$ show the assay schemes for thyrotropin and thyroglobulin.

\section{Statistics}

Non-parametric statistics were used throughout. The Mann-Whitney U-test was used for independent data, the Wilcoxon signed rank test for paired data, the Spearman rank correlation for data comparison and the median and relevant percentiles for the central tendency and dispersion parameters. Because of the skewness of distribution of both thyroglobulin and thyrotropin, double logarithmic transformations of the data were carried out for graphical presentation of results.

\section{Subject and Samples}

Serum samples $(n=164)$ were obtained from children in northern India, Algeria and Peru during a study of the International Council for Control of Iodine Deficiency Disorders (ICCIDD), with the support of UNICEF, before and after different regimes of iodine substitution. The samples were frozen and transported by air to the investigating laboratory, where thyrotropin and thyroglobulin concentrations were determined.

Blood from 304 children in Zimbabwe was spotted onto filter paper, which was then allowed to dry over a two-hour period, before being put into a cellophane envelope. The samples were put into a brief case and delivered to the laboratory 14 days later. The samples were not specially treated and remained at ambient temperature and relative humidity.

The samples were analysed for thyrotropin and thyroglobulin in the laboratory, using identical reagents to those for the serum samples.

A further 54 children from the children's hospital in Lübeck, and with no known thyroid disorders, wère used as controls. The ana- 
Tab. 1a Assay scheme for the thyrotropin (TSH) assay.

a. Coating of microtitre plate wells - reagents for 1 plate $(=96$ wells)

1. $75 \mu \mathrm{l}$ monoclonal anti-TSH $+30 \mathrm{ml} 0.05 \mathrm{~mol} / \mathrm{l}$ phosphate buffer, $\mathrm{pH}$ 8.7. Pipette $300 \mu \mathrm{I}$ into each well and allow to stand at $4{ }^{\circ} \mathrm{C}$ overnight. (The plates can be stored sealed at this point for several weeks, without noticeable loss in binding capacity or precision.)

2. Wash the plate with $3 \times 300 \mu$ l demineralised water and pipette $400 \mu \mathrm{l}$ post-coating solution $(1 \mathrm{~g} / \mathrm{l}$ bovine serum albumin in 0.05 $\mathrm{mol} / \mathrm{l}$ carbonate buffer, $\mathrm{pH} \mathrm{9.6)}$ and allow to stand for $60 \mathrm{~min}$.

3. Wash the plate with $3 \times 300 \mu \mathrm{l}$ wash solution $(0.25 \mathrm{ml} / \mathrm{l}$ Triton $\mathrm{X}-405$ in $0.025 \mathrm{~mol} / 1 \mathrm{Tris}-\mathrm{HCl}, \mathrm{pH} 7.5$ ). The plate is now ready for use.

b. Assay

1. 1 blood-spot ( $3 \mathrm{~mm}$ diameter) or $100 \mu$ serum.

$200 \mu$ l polyclonal anti-TSH-biotin (sheep) in assay buffer $(0.05$ $\mathrm{mol} / \mathrm{l}$ phosphate, $0.07 \mathrm{~mol} / \mathrm{l} \mathrm{NaCl}, 0.15 \mathrm{ml} / /$ Triton X-405, $1 \mathrm{ml} / \mathrm{l}$ mouse serum, $1 \mathrm{ml} / 1 \mathrm{MAK}-33,0.15 \mathrm{~mol} / 1 \mathrm{NaN}_{3}, \mathrm{pH} 7.6$ ).

Incubate on a microtitre plate shaker $4 \mathrm{~h}$ at ambient temperature. Wash with $6 \times 300 \mu \mathrm{l}$ wash solution.

$200 \mu$ Streptavidin-Eu ${ }^{+3}(\approx 20 \mathrm{ng}$ Streptavidin) in DELFIA buffer.

Incubate for $30 \mathrm{~min}$ and wash as above.

$200 \mu$ l Enhancement solution.

Mix and let stand for $30 \mathrm{~min}$, transfer plate to ARCUS 1232 time resolved fluorimeter and measure each well for $1 \mathrm{~s}$.

Standard curve concentrations: $0,10,25,50,100,250 \mathrm{mU} / 1 \mathrm{TSH}$ (Kabi) in EDTA blood, baematocrit 0.45 . The zero standard was made up in foetal calf serum/EDTA/erythrocyte concentrate with the same haematocrit.

[Serum assay standards in assay buffer: $0,0.01,0.1,1,5,50 \mathrm{mU} / \mathrm{l}$.]

Tab. 1b Assay scheme for thyroglobulin (Tg) assay.

a. Coating of microtitre plates

Coating was similar to that for the TSH assay, but replacing the anti-TSH with $15 \mu \mathrm{l}$ anti-Tg (DAKO - Cat. No. A 251) per plate. The $\mathrm{pH}$ of the coating buffer was 8.65. Post-coating was carried out as for TSH.

\section{b. Assay}

1 blood-spot ( $3 \mathrm{~mm}$ diameter) or $50 \mu \mathrm{l} \mathrm{serum}$.

$200 \mu \mathrm{l}$ Anti-thyroglobulin-biotin.

1 Anti-thyroglobulin coated well.

Incubate and proceed as for thyrotropin assay in table 1 a.

The assay buffer contained $10 \mathrm{ml} / 1$ rabbit serum instead of mouse serum, and no MAK-33 was added.

Standard curve concentrations: $0,5,20,50,200,500 \mu \mathrm{g} / \mathrm{l}$ human thyroglobulin (Henning-Berlin) in EDTA blood with a haematocrit of 0.42 . Blood was obtained from a thyroidectomised patient with an anti-thyroglobulin titre of less than $10 \mathrm{kU} / \mathrm{l}$ and a thyroglobulin concentration not significantly different from the zero standard in both the Henning kit and in-house assay.

[Serum assay standards in serum from same patient: $0,1,5,10$, 50, 250, $1000 \mu \mathrm{g} / \mathrm{l}$. lysed blood was EDTA blood drawn for routine laboratory tests. Both plasma and blood spot thyroglobulin was determined. Thyrotropin concentrations were only measured in serum in the control group.

\section{Studies and Results}

\section{Evaluation of the assays}

The dry blood spot assay for thyrotropin was compared with the Pharmacia DELFIA TSH-kit for neonatal screening. The dry blood spot test for thyroglobulin could not be compared directly with another method.

The thyroglobulin immunofluorimetric assay developed here was compared with the immunoluminometric assay from Henning Berlin on serum samples only, as the latter was not conceived for dry-blood spots.

Intra-assay precision was determined from precision profiles, inter-assay precision in the accepted manner. Results are shown in tables $2 a$ and $2 b$ for dry blood spots and in tables $2 \mathrm{c}$ and $2 \mathrm{~d}$ for serum samples.

Comparison of dry blood spot thyrotropin and thyroglobulin concentrations in children from an iodine deficient area in Zimbabwe

The samples were obtained as described above and assayed for thyroglobulin and thyrotropin using the assays depicted in tables $1 \mathrm{a}$ and $1 \mathrm{~b}$. The children were aged between 7 and 13 years (median age 10 years).

The thyrotropin concentrations were plotted against the thyroglobulin levels; the results are shown in figures 1a-1c. In figure 1a, all results are plotted, and the correlation coefficient shows a statistically significant correlation between the two analytes $(r=0.314$ before treatment $[p<0.01], r=0.154$ after treatment $[p<0.05]$ ),

Tab. 2a Main quality assessment data for the thyrotropin dry blood spot assay.

a. Intra-assay precision profile data

\begin{tabular}{cll}
\hline $\begin{array}{l}\text { Range } \\
(\mathrm{mU} / 1)\end{array}$ & $\begin{array}{l}\text { No. of } \\
\text { duplicates }\end{array}$ & $\begin{array}{l}\text { Median } \\
\mathrm{CV}(\%)\end{array}$ \\
\hline$<5$ & 220 & 9.5 \\
$5-25$ & 40 & 7.9 \\
$25-250$ & 21 & 7.6 \\
\hline
\end{tabular}

b. Inter-assay precision - data from 15 assays

Control l - mean $3.5 \mathrm{mU} / \mathrm{l}, \mathrm{CV} 14.6 \%$

Control m - mean $22 \mathrm{mU} / \mathrm{l}, \mathrm{CV} 11.9 \%$

Control h - mean $124 \mathrm{mU} / \mathrm{l}, \mathrm{CV} 12.2 \%$

Correlation data: Pharmacia DELFIA (x) vs In-house TRIFMA (y) $\mathrm{n}=196$ data pairs, $\mathrm{r}=0.902$

$y=0.54+0.96 x$ 
Tab. 2b Main quality assessment data for the thyroglobulin dry blood spot assay.

\begin{tabular}{lll}
\hline a. Intra-assay precision profile data & \\
\hline Range & No. of & \\
$(\mu \mathrm{g} / 1)$ & duplicates & Median \\
\hline$<10$ & 116 & $\mathrm{CV}(\%)$ \\
$10-50$ & 110 & 9.1 \\
$50-500$ & 56 & 8.4 \\
\hline
\end{tabular}

b. Inter-assay precision - data from 18 assays

Control 1 - mean $8.9 \mu \mathrm{g} / \mathrm{l}, \mathrm{CV} 13.9 \%$

Control m - mean $66 \mu \mathrm{g} / \mathrm{l}, \mathrm{CV} 12.0 \%$

Control h - mean $206 \mu \mathrm{g} / \mathrm{l}, \mathrm{CV} 11.4 \%$

Correlation data: Henning Lumitest [serum] (x) vs In-house TRIFMA (y)

$\mathrm{n}=104$ data pairs, $\mathrm{r}=0.874$

$y=1.27+0.46 x$

Tab. 2c Main quality assessment data for the thyrotropin serum assay.

\begin{tabular}{lll} 
a. Intra-assay precision profile data & \\
\hline $\begin{array}{l}\text { Range } \\
\text { (mU/l) }\end{array}$ & $\begin{array}{l}\text { No. of } \\
\text { duplicates }\end{array}$ & $\begin{array}{l}\text { Median } \\
\text { CV (\%) }\end{array}$ \\
\hline$<0.2$ & 45 & 3.5 \\
$0.2-3.5$ & 129 & 2.9 \\
$3.5-50$ & 62 & 2.8
\end{tabular}

b. Inter-assay precision - data from 12 assays

Control 1 - mean $0.6 \mathrm{mU} / \mathrm{l}, \mathrm{CV} 4.9 \%$

Control m - mean $3.7 \mathrm{mU} / \mathrm{l}, \mathrm{CV} 4.8 \%$

Control h - mean $27 \mathrm{mU} / \mathrm{l}, \mathrm{CV} 4.8 \%$

Correlation data: Behring Berilux (x) vs In-house TRIFMA (y) $\mathrm{n}=224$ data pairs, $\mathrm{r}=0.925$

$y=0.04+1.08 x$

Tab. 2d Main quality assessment data for the thyroglobulin serum assay.

a. Intra-assay - precision profile data

\begin{tabular}{lcl}
\hline $\begin{array}{l}\text { Range } \\
(\mu \mathrm{g} / \mathrm{l})\end{array}$ & $\begin{array}{l}\text { No. of } \\
\text { duplicates }\end{array}$ & $\begin{array}{l}\text { Median } \\
\mathrm{CV}(\%)\end{array}$ \\
\hline$<1-5$ & 46 & $\cdot$ \\
$5-40$ & 147 & 3.1 \\
$40-1000$ & 49 & 2.8 \\
\hline
\end{tabular}

b. Inter-assay precision - data from 12 assays

Control 1 - mean $3.8 \mu \mathrm{g} / \mathrm{l}, \mathrm{CV} 4.9 \%$

Control $\mathrm{m}$ - mean $37 \mu \mathrm{g} / \mathrm{l}, \mathrm{CV} 4.7 \%$

Control h - mean $336 \mu \mathrm{g} / \mathrm{l}, \mathrm{CV} 5.0 \%$

Correlation data: Henning Lumitest (x) vs In-house TRIFMA (y) $\mathrm{n}=122$ data pairs, $\mathrm{r}=0.901$

$y=2.04+0.99 x$

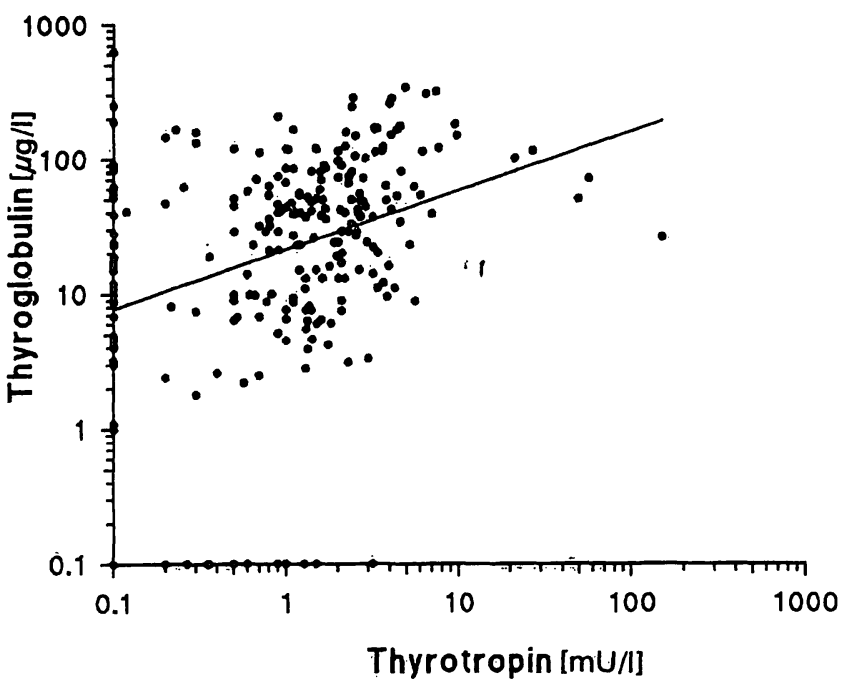

Fig. 1a Plot of thyrotropin (x) against thyroglobulin (y) as measured in dry blood spots from 304 children in Zimbabwe. Values lying below the lower detection limit of each assay were entered as $0.1 \mathrm{mU} / \mathrm{l}$. There is a mathematically significant correlation between both analytes $(r=0.304, p<0.01)$, although the spread of results is large. The regression line is given by the equation: (log y) $=0.372(\log \mathrm{x})+1.32$.

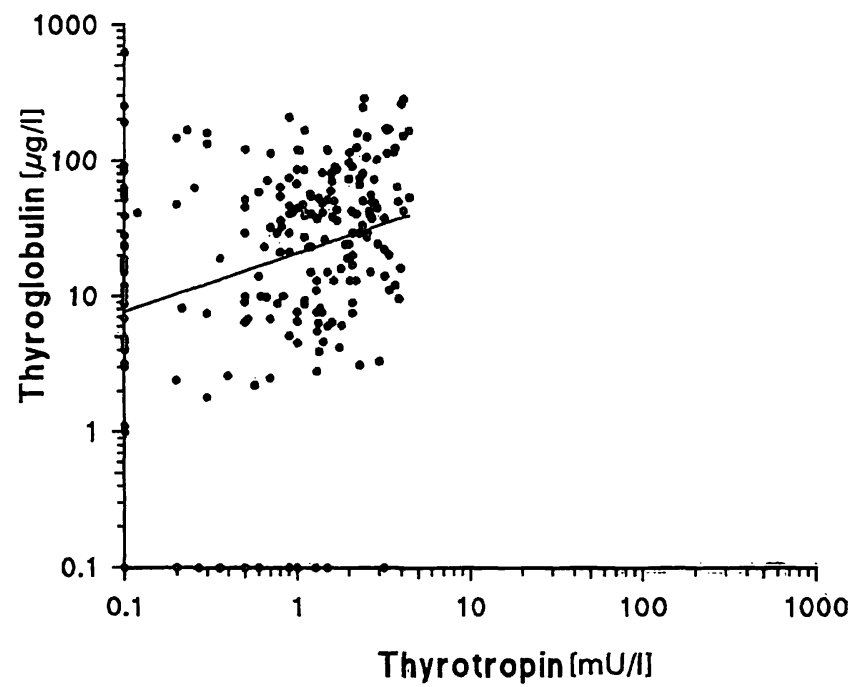

Fig. 1b As figure 1a, but using the values for thyrotropin which lay below the cut-off of $4.5 \mathrm{mU} / 1.276$ children are depicted in this figure. Again there is a statistically significant correlation between thyrotropin and thyroglobulin $(r=0.281, p<0.01)$. The regression line is given by the equation: $(\log y)=0.427(\log x)+1.32$.

although the scatter of results is large. Although the thyroglobulin values were significantly lower after therapy (median before therapy $29 \mu \mathrm{g} / \mathrm{l}$, after therapy $13 \mu \mathrm{g} / \mathrm{l}$, $[\mathrm{p}<0.001]$ ) this was not the case for thyrotropin (median before therapy $1.2 \mathrm{mU} / \mathrm{l}$, after therapy $<1 \mathrm{mU} / 1$, $[\mathrm{p}<0.1])$.

If the results are split into two groups, by using a thyrotropin value of $4.5 \mathrm{mU} / \mathrm{l}$ as cut-off (lower limit of hypothyroid range for blood=spot samples), then a different picture emerges. Figure $1 \mathrm{~b}$ shows the scatter of results in 


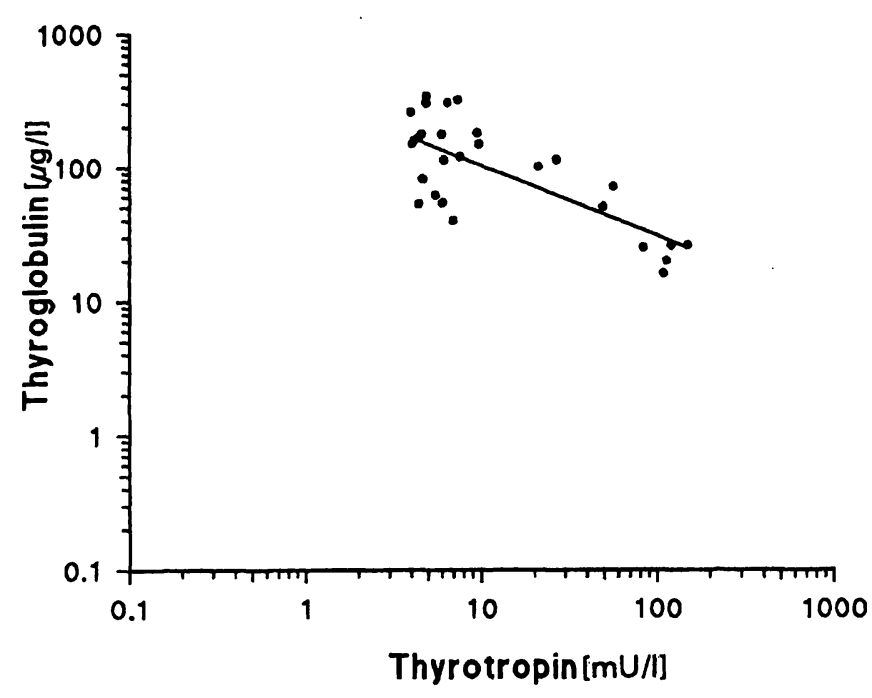

Fig. 1c This figure shows the remaining 28 children with thyrotropin values above $4.5 \mathrm{mU} /$. Here, in contrast to figures $1 \mathrm{a}$ and $\mathrm{lb}$, there is a strong negative correlation between the two analytes $(r=-0.74, p .<0.01)$, supporting the theory that thyrotropin level do not become elevated until the thyroid gland is no longer able to secrete sufficient active thyroid hormones, which appears to be at a relatively late stage of iodine deficiency. The regression line is given by the equation: $(\log y)=-0.525(\log x)+2.58$.

children with thyrotropin levels in the euthyroid range, whereas figure $1 \mathrm{c}$ shows the scatter for children with elevated thyrotropin levels, i. e. in the overt hypothyroid range. Although the thyrotropin levels in figure la show a positive correlation with thyroglobulin, the elevated thyrotropin levels (fig. 1c) show a strong negative correlation. Only $28 / 304(9.2 \%)$ of the children in the Zimbabwe study had elevated thyrotropin concentrations, compared with $182 / 304(60 \%)$ with elevated thyroglobulin, using cut-off values of $4.5 \mathrm{mU} / 1$ for thyrotropin and $20 \mu \mathrm{g} / \mathrm{l}$ for thyroglobulin in blood spots. 213/304 (70\%) children had enlarged thyroid glands. The results show that thyroglobulin is a more sensitive indicator of goitre than thyrotropin in children in an area of severe iodine deficiency.

\section{Results from children under different iodine therapy regimes in Algeria, Peru and India, using serum thyroglobulin and antibodies to thyroid peroxidase as markers}

Four groups of 20 children were each given a different dose of iodine orally in the form of iodised oil (Lipiodol). One group of 20 children was given a single injection of iodised oil.

Serum thyroglobulin and antibodies to thyroid peroxidase were measured before and one year after treatment. Only results from children with both of these blood
Tab. 3 Thyroglobulin levels in serum, before and one year after single dose iodine therapy.

Iodised oil (Lipiodol) treatment - oral (India, Peru)

Group A - $120 \mathrm{mg}$ iodine $(n=14)$

Before treatment - median $186 \mu \mathrm{g} / \mathrm{l}$ (range 17-365 $\mu \mathrm{g} / \mathrm{l}$ )

After treatment - median $91.5 \mu \mathrm{g} / 1$ (range $14-513 \mu \mathrm{g} / \mathrm{l}$ )

Group B - $240 \mathrm{mg}$ iodine $(\mathrm{n}=10)$

Before treatment - median $62.5 \mu \mathrm{g} / \mathrm{l}$ (range $14-142 \mu \mathrm{g} / \mathrm{l}$ )

After treatment - median $25.5 \mu \mathrm{g} / \mathrm{l}$ (range 6.6-31 $\mu \mathrm{g} / \mathrm{l}$ )

Group C - $480 \mathrm{mg}$ iodine $(\mathrm{n}=9)$

Before treatment - median $264 \mu \mathrm{g} / 1$ (range $78-540 \mu \mathrm{g} / \mathrm{l}$ )

After treatment - median $5.5 \mu \mathrm{g} / \mathrm{l}$ (range $<5-48 \mu \mathrm{g} / \mathrm{l}$ )

Group D - $960 \mathrm{mg}$ iodine $(\mathrm{n}=8)$

Before treatment - median $69.5 \mu \mathrm{g} / \mathrm{l}$ (range $42-120 \mu \mathrm{g} / \mathrm{l}$ )

After treatment - median $39.5 \mu \mathrm{g} / 1$ (range $<5-74 \mu \mathrm{g} / \mathrm{l}$ )

Iodised oil injection (Algeria)

Group E - $480 \mathrm{mg}$ iodine $(\mathrm{n}=12)$

Before treatment - median $48.0 \mu \mathrm{g} / \mathrm{l}$ (range $20-496 \mu \mathrm{g} / \mathrm{l}$ )

After treatment - median $11.5 \mu \mathrm{g} / 1$ (range $5.4-22 \mu \mathrm{g} / \mathrm{l}$ )

Comparison of results before and after treatment, using the Wilcoxon signed rank test, showed $\mathrm{p}<0.01$ in all cases.

samples have been used, so that the numbers in each group range from $8-14$ children. The low "recovery rate" was due to the nomadic life pattern of those studied. It is accepted by the authors that these results have only limited statistical validity.

Four dose levels of oral iodine (120, 240, 480 and 960 $\mathrm{mg}$ ) and one injection of iodised oil $(480 \mathrm{mg}$ ) were chosen. The results of the thyroglobulin levels are shown in table 3.

It can be seen that the low-level oral iodine regime did not lead to a reduction of serum thyroglobulin to normal levels (Group A), whereas the intermediate regime (Groups B and C) showed increasingly normal thyroglobulin levels one year after therapy. The high dose group (Group D) had, with one exception, normal thyroglobulin levels one year after treatment.

The children given a single injection of iodised oil (group E) showed normal thyroglobulin levels one year later.

There was little difference in the post-treatment thyroglobulin levels of Groups D and E, which showed that a single oral dose of $960 \mathrm{mg}$ iodine, given as iodised oil, had almost the same effect as $480 \mathrm{mg}$ iodine given intramuscularly.

In no case were antibodies to thyroid peroxidase positive, either before or after therapy. 
Control group of children with no known thyroid disorders

Thyrotropin and thyroglobulin were measured in both dry blood spots and serum from 54 children from the University Children's Hospital in Lübeck.

The median serum thyrotropin level was $1.2 \mathrm{mU} / 1$ (range 0.26-3.2 mU/l) and median serum thyroglobulin level $18 \mu \mathrm{g} / \mathrm{l}$ range $2.5-53 \mu \mathrm{g} / \mathrm{l})$. The median dry blood spot thyrotropin was $0.65 \mathrm{mU} / \mathrm{l}$ (ranging from not detectable $(<0.5 \mathrm{mU} / \mathrm{l})$ to $2.0 \mathrm{mU} / \mathrm{l})$, the median blood spot thyroglobulin level $12 \mu \mathrm{g} / \mathrm{l}$ (ranging from not detectable $(<2.5 \mu \mathrm{g} / \mathrm{l})$ to $37 \mu \mathrm{g} / \mathrm{l})$. One child with athyroidism had a thyroglobulin level below the detection limit of both serum and dry blood spot assays.

\section{Discussion}

The results show that both thyrotropin and thyroglobulin can be assayed in dried blood spots. This makes the acquisition, storage and transport of samples practical in regions which are either difficult to reach, or which are underdeveloped with regard to modern laboratory technology $(5,6)$. It is also probably advantageous to take blood spot samples in areas in which the danger of viral, bacterial or parasite infection is high. The stability of thyroid hormones on filter paper has been documented (9).

The reduction of storage space, not only for samples, but also for sampling devices (syringes, needles, disinfection) means that this approach can be used for field studies in areas previously excluded for practical reasons.

The assays developed here in conjunction with ICCIDD showed the excellent lower detection limits available with time resolved fluorescence labelling. In addition, they provided information relevant to the development of a strategy for detecting iodine deficiency.

Thus, in agreement with earlier studies $(10,11)$, thyroglobulin appears to be a more sensitive indicator of iodine deficiency than thyrotropin.

Also, the use of dry blood spot thyroglobulin and thyrotropin neonatal screening would show the absence of the thyroid gland (thyroglobulin levels undetectable) and possibly allow an estimate of the gland size (12).

Figures $1 \mathrm{~b}$ and $1 \mathrm{c}$ are interesting inasmuch as they may show a two-phase reaction at the thyroid pituitary level.

In the first phase, the thyroid can compensate for the iodine deficiency by increasing its volume and its potential for thyroxine production. The increased release of thyroglobulin reflects the increase in synthetic activity in the form of scavenging. Not only thyroid hormones, but also their precursors, still attached to thyroglobulin, are released. The result is that the pituitary does not react at this stage, which is reflected by the mainly euthyroid thyrotropin levels. In the second phase, the thyroid gland is no longer able to secrete enough thyroid hormones or to synthesise sufficient thyroglobulin.

In such cases of advanced goitre with reduced free thyroid hormone levels, the central regulation takes over, resulting in an increase of thyrotropin levels in serum. This has little or no effect on the thyroid hormone production from the damaged thyroid, and is reflected in the decrease of thyroglobulin levels in serum.

Further interpolation of these results may lead to the postulation of two independent mechanisms of thyroid hormone production and control, one operating at the cell nucleus-thyroid level, reflected in figure $1 \mathrm{~b}$, and one at the cell nucleus-thyroid-pituitary level shown in figure $1 c$.

The results from the iodine therapy groups (Groups A-E, table 3) show that even at advanced stages of iodine deficiency, reflected in the grossly elevated thyroglobulin levels in serum, normalisation can be achieved with simple iodine therapy in the form of iodised oil. Here it can also be seen that although oral iodine application is not as effective (Group C) when compared with the same amount given by injection (Group E), this can be compensated for by doubling the oral dosage (Group D).

The results from Zimbabwe, together with the results from the iodine therapy group, indicate that serum thyroglobulin is a more sensitive indicator of iodine deficiency than serum thyrotropin and should therefore be used in the diagnosis and control of therapy of iodine deficiency. This may only apply to those areas in the world studied here, in which severe iodine deficiency is still prevalent, but also to countries in which moderate and mild iodine deficiency is present, including large areas of Europe.

It must be borne in mind that these results were obtained from children in areas of extreme iodine deficiency, and may not be transferable to areas of mild deficiency, although results from this laboratory (10) have showin that thyroglobulin levels are elevated in hypothyroid newborns, and that they return to normal under thyroxine treatment. Further studies must be carried out to follow up these findings, using serum thyroglobulin, other analytes, and quantities such as thyroid volume and urinary iodide before and after treatment or supplementation.

\section{Acknowledgement}

The authors acknowledge the technical assistence of Frau Thora Konermann, Frau Ulrike Gaida, Frau Jutta Jäger and Frau Christine Wolanin. 


\section{References}

1. Irie, M., Enomoto, K. \& Naruse, H. (1975) Measurement of thyroid stimulating hormone in dried blood spot. Lancet $i i$, $1233-1234$.

2. Larsen, P. R. \& Broskin, I. (1975) Thyroxin $\left(T_{4}\right)$ immunoassay using filter paper blood samples for screening of neonates for hypothyroidism. Pediatr. Res. 9, 604-609.

3. Delange, F. (1979) Neonatal screening for congenital hypothyroidism in Europe. Report of the newborn committee of the European Thyroid Association. Acta Endocrinol. (Kbh.) Suppl. 223, 3-29.

4. Boyages, S. C., Halpern, J. P., Maberly, G. F., Collins, J., Jupp, J., Eastman, C. J., Jin, C. E., Gu, Y. H. \& Zhou, L. (1990) Supplementary iodine fails to reverse hypothyroidism in adolescents and adults with endemic cretinism. J. Clin. Endocrinol. Metab. 70, 336-341.

5. Aebischer, M. L., Martorana, M. C., Costa, F., Battaggia, C., Madera, A., Destito, D., Machera, F., Bailly, C. \& Angeloni, P. (1990) Evaluation of the sensitivity of microfilter paper assays in an anthropological study: Results of samples from Cameroon and Tanzania. Anthropol. Anz. 48, 15-23.

6. Wachter, W., Mvungi, M. G., van Thiel, D., Marschner, I., Wood, W. G., Pickardt, C. R. \& Scriba, P. C. (1985) Iodine deficiency, hypothyroidism and endemic goitre in Southern Tanzania. lodine deficiency, hypothyroidism and endemic goitre in Southern Tanzania. J. Epid. Comm. Health 39, 263270.
7. Mißler, U., Gaida, U. \& Wood, W. G. (1993) Development and evaluation of a time-resolved immunofluorimetric assay for thyrotropin. Eur. J. Clin. Chem. Clin. Biochem. 31, 389393.

8. Wood, W. G. (1989) A universal solid-phase immunoassay system based on avidin-biotin reagents. Ärztl. Lab. 35, 29-34.

9. Waite, K. V., Maberly, G. F. \& Eastman, C. J. (1987) Storage conditions and stability of thyrotropin and thyroid hormones on filter paper. Clin. Chem. 33, 853-855.

10. Baumann, P. \& Wood, W. G. (1985) Serum thyroglobulin concentrations in the first weeks of life as measured with an immunoluminometric assay. J. Clin. Chem. Clin. Biochem. 23, 753-758.

11. Sava, L., Tomaselli, L., Runello, F., Belfiore, A. \& Vigneri, R. (1986) Serum thyroglobulin levels are elevated in newborns

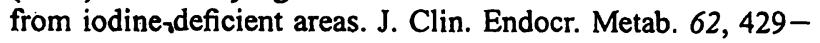
432.

12. Léger, J., Schlumberger, M. \& Czernichow, P. (1986) Diagnostic étiologique de l'hypothyroïde congénital et thyroglobuline plasmatique. Arch. Fr. Pediatr. 43, 179-182.

Prof. Dr. W. G. Wood

Institut für Klinische Laboratoriumsdiagnostik

Klinikum der Hansestadt Stralsund

P. O. Box 103

D-18402 Stralsund

Germany 
. 